Cooke, S. J. 2021. A fisheries take on the fishy decision to implement a Double-crested Cormorant cull in Ontario. Avian Conservation and Ecology 16(2):16. https://doi.org/10.5751/ACE-02017-160216

Copyright (C) 2021 by the author(s). Published here under license by the Resilience Alliance.

\title{
A fisheries take on the fishy decision to implement a Double-crested Cormorant cull in Ontario
}

\author{
Steven J. Cooke ${ }^{1}$ \\ ${ }^{1}$ Fish Ecology and Conservation Physiology Laboratory, Department of Biology and Institute of Environmental and \\ Interdisciplinary Science, Carleton University
}

Key Words: cormorant; cull; evidence; fish; resource management

\section{INTRODUCTION}

I thoroughly enjoyed reading the candid editorial by Keith Hobson (Hobson 2021) where he thoughtfully explored the misguided genesis of the province-wide Double-crested Cormorant (Phalacrocorax auritus) cull instituted in Ontario, Canada, in 2020. The editorial was aptly published in an avian conservation journal and was authored by an expert in avian ecology. At the end of the editorial Hobson welcomed lucid, evidence-based rebuttals. As a fish ecologist there is nothing in the article that I wish to rebut. Rather, I wish to amplify the message and do so from the perspective of the fish. Much of the commentary, news, and advocacy arising from this issue has come from those with deep expertise and connections to birds. Yet, given that the primary reason given for the cull tends to be rooted in fisheries science, it only makes sense that the fisheries science community also weighs in. I am also a strong advocate for evidence-based conservation and environmental management, which is highly relevant to this unique example where evidence is notably absent. Below I make four key points.

\section{Fish populations in Ontario are not doing so well but cormorants are not to blame}

There is no doubt that freshwater biodiversity (including fish) is in crisis (Harrison et al. 2018). A recent pan-Canadian assessment suggests that $18.7 \%$ of freshwater-dependent fish species in Canada are considered to be at risk (Desforges et al. 2021). The same can be said for Ontario where species like redside dace (Clinostomus elongatus) and river redhorse (Moxostoma carinatum) are doing rather poorly. Yet, most fish populations targeted by recreational anglers are doing well (Cooke 2021; but see Post et al. 2002) in large part because of the reliance on sciencebased management, e.g., use of various regulations informed by routine stock assessment. The threats are real: overfishing, invasive species, pollution, habitat loss/alteration, and climate change along with emerging threats (Reid et al. 2019). Yet, if one were to make a list of the threats that face freshwater fish populations in Ontario (or Canada), cormorants would be down the list, near the very bottom. Despite the recent population recovery of cormorants, they would be positioned alongside other endemic freshwater piscivorous organisms such as Common Loons (Gavia immer), Western Osprey (Pandion haliaetus),
American mink (Neogale vison), and North American river otters (Lontra canadensis). The real drivers of fish population declines are humans. We alter habitat, we pollute, we are responsible for climate change, we introduce non-native species, and we overharvest (Reid et al. 2019). To be clear, there is no doubt that cormorants eat fish, but evidence that supports their role in contributing to broad-scale population declines is notably absent. A recent comprehensive meta-analysis failed to detect a statistically significant effect of cormorants (of all species) on (marine and freshwater) fish populations (Ovegård et al. 2021). As pointed out by Hobson (2021), it is entirely possible for there to be very localized issues, e.g., in a given embayment or a small lake, at fish farms (see Ovegård et al. 2021) where predation could be at a level that conflicts with achieving fisheries management objectives. In such cases there MAY be reason to engage in some local culling or hazing but such measures should be applied in a tactical manner, not applied at a provincial (or state) scale as has occurred with the Ontario province-wide cormorant cull. Moreover, fisheries management objectives need to be considered in a broader framework where other aspects of ecosystems are valued and considered (Gisalson et al. 2000).

\section{Attention focused on cormorants is misguided and draws attention away from} the real issues

Given the dire state of freshwater biodiversity, an emergency action plan was developed by an international team of scientists and practitioners in an effort to protect and restore freshwater ecosystems (Tickner et al. 2020). Nowhere in the plan is there suggestion that culling piscivorous birds (or any native predators) would benefit biodiversity. Indeed, a key aspect of the plan is engaging stakeholders and rights holders so they understand the value of aquatic biodiversity and both support (e.g., through how they vote, how they donate) or directly engage in conservation actions (e.g., doing hands-on habitat restoration). What is particularly concerning with the cormorant cull is that it gives the impression that THE threat facing fish populations in Ontario is cormorants, so much so that we needed a province-wide regulation and had to amend laws so that flesh of killed birds could be discarded as trash. What we need is leadership from organizations such as the Ontario Federation of Anglers and 
Hunters (OFAH) and the provincial government in emphasizing the importance of focusing on the REAL threats to our fish populations - as outlined above, almost always one or more of overfishing, invasive species, pollution, habitat loss/alteration, and climate change. It is convenient how focusing on cormorants removes the responsibility of resource users and other citizens of Ontario and puts the attention on cormorants. When this fails, one might surmise that (gun) sights may be set on other piscivorous birds like loons or osprey. I can only wonder what good could have come had all of the effort focused by OFAH (and other organizations and individuals) on advocating for the cormorant cull or the time spent by those engaging in the cull been focused on, say, better freshwater habitat protections or restoration initiatives.

\section{Piscivorous birds benefit fish and aquatic ecosystems}

Predation is a natural biological phenomenon. Carnivorous or omnivorous animals of all sorts need to eat other animals to survive. A recent synthesis has explored the ecosystem services (regulating food webs, cycling nutrients, engineering habitats, mitigating diseases/parasites, and mediating ecological invasions) generated by aquatic predators such as cormorants (Hammerschlag et al. 2019). For example, predators can initiate trophic cascades within and across ecosystems that can even influence water quality. A study of Great Cormorants (Phalacrocorax carbo) revealed that consumption of zooplanktivorous fish by cormorants reduced eutrophication by releasing pressure on zooplankton (van Eerden et al. 1995). Aquatic predators can also promote biodiversity among prey species by reducing competitive exclusion by dominant prey (Terborgh 2015). Cormorants cycle nutrients via excretion and egestion while also sequestering nutrients in body tissues. Because they are mobile they redistribute nutrients. Given that cormorant roosting sites are often associated with high levels of excretion that leads to defaunation, they also play a role as ecosystem engineers, benefitting organisms such as small mammals (Jasiulionis et al. 2021) and increasing habitat heterogeneity (Kolb et al. 2012). Aquatic predators are known to select prey fish that are in poor health, which may reduce disease transmission among fish (Hammerschlag et al. 2019). Aquatic predators can also consume invasive species, which has been documented for Double-crested Cormorants that prey on invasive round goby (Neogobius melanostomus; Johnson et al. 2010). When endemic aquatic predators such as cormorants are culled there are almost always dramatic shifts in ecosystem structure and function (Hammerschlag et al. 2019).

\section{On the erosion of evidence-based natural resource management}

I am so confident in the position shared here that a province-wide cormorant cull will be of no benefit to fish populations in Ontario that it is unlikely that any independent fisheries professional would refute it. What is alarming is that I believe this perspective is also held by the environmental professionals that work for the Ontario Ministry of Natural Resources and Forestry (MNRF; recently renamed the Ontario Ministry of Northern Development, Mines, Natural Resources and Forestry). A CBC news article that involved Freedom of Information requests revealed that MNRF scientists raised substantial concerns about the cull (https://www.cbc.ca/news/canada/ottawa/double-crestedcormorant-hunting-mnrf-staff-concerns-1.5053685) and suggested that "It undermines the integrity of the MNRF as a science-based, sustainability-focused resource management agency." As noted above, MNRF has traditionally been a science-based organization with exceptional internal science capacity, sciencemanagement frameworks, and a track record of partnering with external scientists. It is possible (albeit highly unlikely) that there is a massive amount of evidence supporting the province-wide cormorant cull. If that is the case, such evidence has not been shared with the public or the scientific community. As most governments in Canada move toward an open science framework (see Roche et al. 2020), the MNRF under the Ford government seems to be moving backward and has become less open and transparent. The reason this issue has resonated so much with the science community in Ontario is because it signals the erosion of evidence-based natural resource management and the unhealthy influence of some public interest groups. A related issue is the absence of discussions about the cormorant cull with the Fisheries Management Zone (FMZ) councils across the province. These regional bodies comprised stakeholders and rights holders and work collaboratively to develop regional (zone specific) fisheries management plans. As a member of FMZ 18, I can attest that cormorants have never been discussed at our meetings (by members or MNRF staff) nor does the word cormorant appear in our zone fisheries management plan. Yet, FMZ 18, like all zones in the province, is included in the cull. I recognize that the cull is in the domain of wildlife management yet the justification for the cull is entirely about fisheries management.

\section{CONCLUSION}

Resource management in Ontario, across Canada, and elsewhere remains imperfect (e.g., Artelle et al. 2018, Hessami et al. 2021), yet we are fortunate in Ontario to have science-based management agencies as well as mechanisms (like the FMZ councils) to engage with local resource stewards. Robust and reliable evidence should guide environmental decision making through inclusive and transparent processes; there is a history of doing so in Canada (Cooke et al. 2016). The province-wide Double-crested Cormorant cull will stand out for decades as a textbook example of misguided management that lacks any evidentiary basis (Ford et al. 2021). The diverse emotions and feelings held by individuals about this issue are all valid, but good environmental policy should be based on evidence and not emotion. As a fish ecologist this represents my first contribution to an avian journal, a paper that I wish I did not have to write. I echo and amplify the wise words of Hobson in his editorial. We must demand more from our governments and ensure that evidence-based decision making is normalized, and not abandoned when inconvenient.

\section{CONFLICT OF INTEREST STATEMENT}

Cooke is an avid angler and occasional hunter.

Responses to this article can be read online at: https://www.ace-eco.org/issues/responses.php/2017 


\section{LITERATURE CITED}

Artelle, K. A., J. D. Reynolds, A. Treves, J. C. Walsh, P. C. Paquet, and C. T. Darimont. 2018. Hallmarks of science missing from North American wildlife management. Science Advances 4(3): eaao0167. https://doi.org/10.1126/sciadv.aao0167

Cooke, S. J. 2021. How are freshwater fish populations in Canada REALLY doing in Canada? Just Fishing Magazine. Spring Issue, Page 16.

Cooke, S. J., J. C. Rice, K. A. Prior, R. Bloom, O. Jensen, D. R. Browne, L. A. Donaldson, J. R. Bennett, J. C. Vermaire, and G. Auld. 2016. The Canadian context for evidence-based conservation and environmental management. Environmental Evidence 5:14. https://doi.org/10.1186/s13750-016-0065-8

Desforges, J. E., J. Clarke, E. J. Harmsen, A. M. Jardine, J. A. Robichaud, S. Serré, P. Chakrabarty, J. R. Bennett, D. E. L. Hanna, J. P. Smol, et al. 2021. On the alarming state of freshwater biodiversity in Canada. Canadian Journal of Fisheries and Aquatic Sciences. https://doi.org/10.1139/cjfas-2021-0073

Ford, A. T., A. H. Ali, S. R. Colla, S. J. Cooke, C. T. Lamb, J. Pittman, D. S. Shiffman, and N. J. Singh. 2021. Understanding and avoiding misplaced efforts in conservation. FACETS 6:252-271. https://doi.org/10.1139/facets-2020-0058

Gislason, H., M. Sinclair, K. Sainsbury, and R. O'Boyle. 2000. Symposium overview: incorporating ecosystem objectives within fisheries management. ICES Journal of Marine Science 57 (3):468-475. https://doi.org/10.1006/jmsc.2000.0741

Hammerschlag, N., O. J. Schmitz, A. S. Flecker, K. D. Lafferty, A. Sih, T. B. Atwood, A. J. Gallagher, D. J. Irschick, R. Skubel, and S. J. Cooke. 2019. Ecosystem function and services of aquatic predators in the Anthropocene. Trends in Ecology \& Evolution 34(4):369-383. https://doi.org/10.1016/j.tree.2019.01.005

Harrison, I., R. Abell, W. Darwall, M. L. Thieme, D. Tickner, and I. Timboe. 2018. The freshwater biodiversity crisis. Science 362(6421):1369. https://doi.org/10.1126/science.aav9242

Hessami, M. A., E. Bowles, J. N. Popp, and A. T. Ford. 2021. Indigenizing the North American model of wildlife conservation. FACETS 6:1285-1306. https://doi.org/10.1139/facets-2020-0088

Hobson, K. A. 2021. Ontario's decision for the province-wide cull of Double-crested Cormorants. Avian Conservation and Ecology 16(1):24. https://doi.org/10.5751/ace-01949-160124

Jasiulionis, M., L. Balčiauskas, and L. Balèiauskienè. 2021. Impact of the colonies of Great Cormorants (Phalacrocorax carbo sinensis) on small mammals communities. The $1^{\text {st }}$ International Electronic Conference on Biological Diversity,
Ecology and Evolution 15-31 March 2021. https://doi. org/10.3390/bdee2021-09441

Johnson, J. H., R. M. Ross, R. D. McCullough, and A. Mathers. 2010. Diet shift of Double-crested Cormorants in eastern Lake Ontario associated with the expansion of the invasive round goby. Journal of Great Lakes Research 36(2):242-247. https://doi. org/10.1016/j.jglr.2010.02.013

Kolb, G. S., L. Jerling, C. Essenberg, C. Palmborg, and P. A. Hambäck. 2012. The impact of nesting cormorants on plant and arthropod diversity. Ecography 35(8):726-740. https://doi. org/10.1111/j.1600-0587.2011.06808.x

Ovegård, M. K., N. Jepsen, M. Bergenius Nord, and E. Petersson. 2021. Cormorant predation effects on fish populations: a global meta-analysis. Fish and Fisheries 22(3):605-622. https://doi. org/10.1111/faf.12540

Post, J. R., M. Sullivan, S. Cox, N. P. Lester, C. J. Walters, E. A. Parkinson, A. J. Paul, L. Jackson, and B. J. Shuter. 2002. Canada's recreational fisheries: the invisible collapse? Fisheries 27(1):6-17. https://doi.org/10.1577/1548-8446(2002)027<0006:crf>2.0.co;2

Reid, A. J., A. K. Carlson, I. F. Creed, E. J. Eliason, P. A. Gell, P. T. Johnson, K. A. Kidd, T. J. MacCormack, J. D. Olden, S. J. Ormerod, et al. 2019. Emerging threats and persistent conservation challenges for freshwater biodiversity. Biological Reviews 94(3):849-873. https://doi.org/10.1111/brv.12480

Roche, D. G., M. Granados, C. C. Austin, S. Wilson, G. M. Mitchell, P. A. Smith, S. J. Cooke, and J. R. Bennett. 2020. Open government data and environmental science: a federal Canadian perspective. FACETS 5(1):942-962. https://doi.org/10.1139/ facets-2020-0008

Terborgh, J. W. 2015. Toward a trophic theory of species diversity. Proceedings of the National Academy of Sciences 112:11415-11422. https://doi.org/10.1073/pnas.1501070112

Tickner, D., J. J. Opperman, R. Abell, M. Acreman, A. H. Arthington, S. E. Bunn, S. J Cooke, J. Dalton, W. Darwall, G. Edwards, et al. 2020. Bending the curve of global freshwater biodiversity loss: an emergency recovery plan. BioScience 70 (4):330-342. https://doi.org/10.1093/biosci/biaa002

van Eerden, M. R., K. Koffijberg, and M. Platteeuw. 1995. Riding on the crest of the wave: possibilities and limitations for a thriving population of migratory cormorants Phalacrocorax carbo in man-dominated wetlands. Ardea 83(1):1-9.

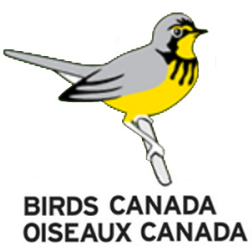

